\title{
Colorectal Cancer Immunotherapy: Current State and Prospects (Review)
}

\author{
DOI: $10.17691 / \mathrm{stm} 2017.9 .3 .18$
}

Received April 12, 2016

0.1. Kit, MD, DSc, Professor, Director"

E.Y. Kirichenko, PhD, Leading Researcher, Head of Laboratory of Functional Genomics and Morphology, Academy of Biology and Biotechnologies named after D.I. Ivanovsky²;

I.A. Novikova, PhD, MD, Head of Laboratory of Tumor Immunophenotyping";

A.Y. Maksimov, MD, DSe, Professor, Assistant Director for Prospective Scientific Research";

S.Y. Filippova, Researcher, Laboratory of Functional Genomics and Morphology, Academy of Biology and Biotechnologies named after D.I. Ivanovsky2;

A.O. Grankina, Junior Researcher, Laboratory of Tumor Immunophenotyping";

E.Y. Zlatnik, MD, DSc, Professor, Chief Researcher, Laboratory of Tumor Immunophenotyping ${ }^{1}$

'Rostov Research Institute of Oncology, 63, 14th Liniya St., Rostov-on-Don, 344037, Russian Federation;

${ }^{2}$ Southern Federal University, 42 Bolshaya Sadovaya St., Rostov-on-Don, 344006, Russian Federation

Currently, new knowledge on immunotherapy in solid tumors is being intensively accumulated and new promising techniques are originating. The most advanced are those in the field of searching for new immune checkpoints, development of highly efficient immune adjuvants based on recombinant viruses to improve the effect of anticancer vaccines, as well as design engineering of chimeric receptors of $T$ cells used for adoptive immunotherapy. We have presented some clinical trial results of immunotherapeutic approaches, as well as experimental studies on animal models, which offer new prospects for colon cancer treatment.

Key words: colorectal cancer; immunotherapy; monoclonal antibodies; adoptive cellular therapy; anticancer vaccine; cytokines.

For the first time the existence of immune surveillance in malignant tumor growth was suggested by Paul Ehrlich in 1909. However, a fundamental theory postulating that all cells undergoing neoplastic alterations are recognized by the immune system and destroyed by cytotoxic T lymphocytes was created in the middle of the twentieth century by Burnet and Thomas [1, 2]. Despite the inconsistency of the postulates, which were promoted by the authors, experimental evidences were obtained long after. The experiments on nude mice with induced oncogenesis revealed no significant increase in tumor incidence compared to immunologically of normal mice [3]. The lack of accomplishment of the first experiments could be due to the fact that athymic nude mice are still not deprived of $T$ cells, as it was demonstrated soon after $[4,5]$.

It was not until the beginning of the twenty-first century that the concept of immune surveillance in malignant tumor growth was proved experimentally by Shankaran [6]. The research was performed on mice with complete loss of lymphocytes due to mutation switching off a recombination activating gene 2 (RAG2) necessary for their differentiation. It was the model that was used to demonstrate for the first time a significant increase in tumor incidence in chemically induced carcinogenesis. The following research intensification in the area of cancer immunotherapy proved the phenomenon of tumor immune editing which means that at early stages of tumor growth, due to the elimination of highly immunogenic clones, predominant accumulation of low immunogenic and even immunosuppressive clones occurs. The tumor ability to avoid the effect of immune system factors is implemented through a number of mechanisms, among them, for example: low expression, or shedding of tumor antigens, molecules of major histocompatibility complex (MHC), coreceptors, induction of $\mathrm{CD}^{+} \mathrm{CD} 25^{+} \mathrm{FoxP} 3^{+}$regulatory T lymphocytes $\left(\mathrm{CD} 8^{+}\right.$and $\left.\mathrm{CD} 4^{+}\right)$suppressing effector lymphocytes, the production of immunosuppressive mediators and autocrine growth factors by the cells of a tumor and of its microenvironment, dysmaturation of dendritic cells (DC), etc. Thus, by the moment of tumor clinical manifestation, natural antitumor mechanisms, as a rule, appear to be suppressed [7].

According to a current concept, immunotherapy is a complex of therapeutic measures aimed at the abolishment of blockade, and the enhancement of antitumor response using the factors of innate and adaptive immunity. The present review contains the term "immunotherapy" in this interpretation.

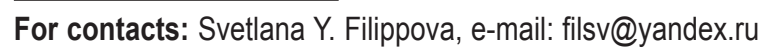


Currently, the colon cancer treatment is based on surgical resection of a tumor combined with adjuvant chemotherapy [8, 9]. The protocol of rectal cancer treatment also includes pre- and postoperative radiotherapy [8]. Despite the fact that the use of target agents blocking epidermal growth factor receptor (EGFR) and vascular endothelial growth factor receptor combined with cytostatic drugs is able to provide some contribution to the enhancement of survival indices for some forms of metastatic colorectal cancer, this type of treatment for colon cancer has not spread widely yet [10-13], therefore the search for new immunotherapeutic agents for colorectal cancer is still relevant.

The present review presents the current clinical trial results of immunotherapeutic approaches, as well as experimental studies on animal models opening new prospects in colon cancer treatment.

\section{Monoclonal antibodies in of colon cancer immunotherapy}

In the absence of Ras gene mutations it is recommended to treat metastatic colon cancer with EGFR-based therapies (cetuximab, panitumumab) [9]. Modern literature describes in detail the principles of their antitumor action [14], it is important to highlight the ability of cetuximab, in addition to direct EGFR inhibition, to induce congenital mechanisms of antibody-dependent cellular cytotoxicity by interacting with FcyRIII (CD16) receptors of natural killers (NK), enhancing their tropism to tumor cells with membrane EGFR [15]. Clinical significance was confirmed by potentiation of the effect when cetuximab was administered along with CD137 agonist - NK co-stimulatory molecule increasing their proliferation [16]. Moreover, even the efficacy of cetuximab in colorectal cancer can depend on a patient's allelic variant FcyRIIIa [17, 18].

In cetuximab, an immunomodulatory effect appeared to be unintended; however, it is likely to induce partially its antitumor effect. The attempts to use targeted monoclonal antibodies for attraction of cytotoxic cells to colon tumor tissue are still rare. The application of mouse monoclonal antibodies anti-EpCAM (edrecolomab), despite most promising results of preliminary clinical trials on patients with colorectal carcinoma [19], phase III of clinical research study did not show significant advantage compared to conventional chemotherapy [20].

There is a relatively new concept that can be referred to immunotherapy, which is based on the same principle of molecular recognition antigen-antibody, i.e., engineering design of chimeric proteins, which have double or multiple specificity for both cancer antigens, and membrane receptors of immune cells. The obtained constructions are vastly superior to monospecific antibodies in efficacy, and have already demonstrated encouraging results in experiments on cell lines and animal models of colorectal carcinoma. Hence, the application of bispecific antibodies of anti-CD3/anti-Her2 resulted in the stimulation of $\mathrm{CD}^{+}$ lymphocyte cytotoxicity to tumor cells in vitro compared to an antibody anti-Her2 (Herceptin), and inhibited the growth of human colon adenocarcinoma xenograft [21]. Attraction of NK into tumor by means of binding of bispecific antibody to antigens CD16 and CD133 typical for stem cells of colorectal carcinoma Caco-2 promoted in vitro cytotoxicity enhancement [22]. The promoting of nonspecific response in colorectal carcinoma tissue was achieved also using the interaction of NKG2D receptor expressed on the surface of NK and some T cells and its ligands. Typically, NKG2D are expressed only on the surface of senescent or malignized cells providing their elimination by the immune system [23]. However, due to the immunoediting, the expression of NKG2D ligands in a tumor is often suppressed [24]. Therefore, the recovery of the interaction so important for tumor elimination by introducing NKG2D ligand associated with the antibody against tumor antigen can be a promising therapeutic method. The efficacy of the technique was demonstrated in a xenograft model of colorectal cancer using a chimeric protein consisting of ULBP2 - NKG2D ligand - and an antibody against a carcinoembryonic antigen (CEA) [25]. No clinical trials of chimeric immunoligands in colorectal cancer have been carried out yet.

High efficiency in the treatment of a number of oncologic diseases was shown by a new group of immunotherapeutics based on antibodies, which target key molecular pathways controlling immune response: the so called immune checkpoints (ICP) [26]. The most extensively studied now are ICP associated with the expression of cytotoxic $T$ lymphocyte-associated antigen 4 (CTLA-4) on a membrane of cytotoxic T lymphocytes, and a programmed cell death receptor 1 (PD-1). Protein CTLA-4 is produced in T lymphocytes after their activation, and serves as a natural inhibitor of a cytotoxic response under normal conditions aimed to restrict autoimmune responses [27]. PD-1 receptor is also expressed on the membrane of activated $T$ lymphocytes, and by interacting with its ligand (PD-L1) causes their apoptosis [28]. PD-L1 molecule is expressed on the surface of various cells, and often its concentration in tumor tissue is increased; that is considered to be one of the main mechanisms to escape an immune response [29].

First significant breakthroughs in administration of the agents based on antibodies to CTLA-4 (ipilimumab) and PD-1 (nivolumab), as well as to PD-L1 in patients with melanoma and non-small cell lung carcinoma [30-33] have inspired numerous studies on the efficacy of antibody and ICP therapy in other types of oncopathologies including colorectal cancer. Though the role of ICP described is considered universal, characteristics of a solid tumor can have an effect on immunotherapy by such antibodies agents. In particular, in literature there is contradictory information on ICP effect in colorectal cancer. On the one hand, according to the information on an increased underlying risk for 
colon cancer in patients carrying single nucleotide polymorphisms in PD-1 gene, one might assume that the interaction between $\mathrm{PD}-1$ and $\mathrm{PD}-\mathrm{L} 1$ participates in colorectal carcinoma growth [34, 35]. Moreover, immune histochemical study showed an increased level of PD-L1 expression in colorectal carcinoma tissues to be associated with the absence of tumor-infiltrating lymphocytes, which correlates with the poorest survival prognosis [36]. Nevertheless, the first studies on the efficiency of antibodies blocking PD-1 and PD-L1 interaction did not demonstrate a significant therapeutic effect in patients with colorectal cancer [30, 32]. Later, it was suggested that a positive response on PD-1 and PD-L1 blockade interaction can be expected only in tumors with microsatellite instability [37] that was confirmed by the following work by Le et al. [38].

The study found the relation of single nucleotide polymorphisms with the predisposition to colon cancer for CTLA-4 gene like for PD-1 [34]. However, the first study of human anti-CTLA-4 monoclonal antibody (tremelimubab) in patents with chemotherapy-resistant types of colon cancer did not yield positive results [39].

Further studies required to determine what treatment regimens switching CTLA-4 and PD-1/PDL1 blocking would be the most effective in colorectal cancer, and identify new ICP, inhibition or stimulation of which would result in the induction of tumor-specific immune response in each kind of oncopathology. $T$ cell immunoglobulin- and mucin-domain-containing molecule-3 (Tim-3) can be held up as an example of a potential candidate for the blockade. It takes part in the suppression of type $1 \mathrm{~T}$ helper and $\mathrm{CD}^{+}$lymphocytes function, its concentration was found to be increased both in blood and tumor tissue of patients with colorectal carcinoma [40]. Besides, it can be effective to use the blockers of lymphocyte activating gene 3 (LAG-3) involved in a negative control of proliferation of a variety of immunocompetent cells, and demonstrating high expression in colorectal carcinoma tissue [41].

In addition to immunosuppressive ICP blocking, the stimulation of activated $\mathrm{T}$ lymphocytes by agonistic antibodies of OX40 receptor promoting their survival can appear to be promising, since there was described a direct relationship of its expression in tumor tissue with a more favorable prognosis in patients with colorectal cancer [42]. Despite the fact that modern therapy of malignancies using ICP blockers and agonists is at the beginning of its development, there is no doubt about the prospects and great potential of the development and implementation of new promising therapeutic decisions for colon cancer.

\section{Anti-tumor vaccines as a tool for colon cancer immunotherapy}

The ultimate objective of vaccination is to induce an effective immune response on tumor providing a longterm control over tumor growth and dissemination.
Currently, there can be distinguished four main vaccination strategies against cancer: 1) application of tumor cell preparations, 2) administration of isolated peptide antigens, 3) use of viral/bacterial vectors, and 4) vaccination using DC. To create a vaccine based on tumor cell preparations implies lysis or radiation of a tumor sample with its following administration to a patient. To enhance immunogenicity of whole cell vaccines, preliminary contamination of tumor cells before radiation is possible including that by recombinant viral vectors expressing co-stimulating molecules, or the combined administration of inactivated tumor material with infectious agents, which could play a role of an immune adjuvant [43]. The strategy was used in a randomized clinical study stage III performed in 50 metastatic colorectal cancer patients to assess the efficiency of vaccination by tumor cells infected by NDV (Newcastle disease virus). In addition, a significant increase in total and recurrence-free survival for patients with colon cancer was found [44].

One of the disadvantages of tumor cell-based vaccines is their low immunogenicity against proper cancer antigens, since tumor tissue contains only a small number of antigens associated with malignant growth, which are significantly exceeded by antigens' amounts and variety expressed in the normal cells.

Increased induction of specific immunity against tumor antigens can be achieved by using a certain peptide or peptide mixture as an agent for vaccination, because the relation between the peptides and malignized tissue was found. Tumor specific antigens were studied for colorectal cancer immunotherapy. According to various researches, the expression of the antigens is increased in colorectal carcinoma tissue, and associated with the poorest prognosis. The increased expression of such antigens as CEA [45], mucin 1 (MUC1) [46], $\beta$-human chorionic gonadotrophin ( $\beta-\mathrm{HCG})$ [47], survivin-2B [48], A2-type ephrin receptor (EphA2) [49], squamous cell carcinoma antigen (SART3) [50] was found in the nucleus and cytosol of adenocarcinoma cells. Positive results of clinical trials were shown after application of vaccine based on $\beta-H C G$, which caused the formation of specific antibodies in 56 of 77 patients, and resulted in total survival growth [51]. The vaccine against MUC1 demonstrated a preventive effect on transplantable tumor model [52] that inspired to search the ways of its application to prevent colorectal cancer growth. The first researches in the field have already shown encouraging results in clinical trials in patients with pre-malignancies in colon inducing a marked humoral response in $43.6 \%$ of them [53].

Despite the immunogenicity of peptide vaccines is higher than of whole cell ones, it is still rather low. The possibility of its increase depends on the use of adjuvants, such as Freund adjuvant, nanoparticles of different origin, alum, and other agents enhancing peptide delivery to DC and/or stimulating pre-immune inflammation in tissues. The development of molecular 
engineering techniques has contributed to the rise of a new high-efficient strategy of combining vaccine with an immune adjuvant - tumor antigen built in a non-replicating infectious vector. Assuming that a viral particle is a strong immunostimulant agent by itself, the molecules enhancing immunocyte response can be additionally built in it. One of the first studies was carried out on colorectal cancer using ALVAC-CEA/ B7.1 vaccine created on the basis of a non-replicating virus: canarypox expressing CEA along with antigen B7.1 responding to the lymphocyte stimulation [54, 55]. Vaccination combined with chemotherapy was found to cause 2.4-fold amount increase of CEA-specific T cells in $31 \%$ patients, an objective clinical response being observed in $40 \%$. CEA/TRICOM vaccine presents a recombinant viral vector expressing CEA, as well as three co-stimulating molecules: B7.1, intercellular cell adhesion molecule-1 (ICAM-1) and lymphocyte functionassociated antigen-3 (LFA-3). It showed high efficiency in mouse colon cancer model and the possibility to be administered safely in patients with metastatic colorectal cancer $[56,57]$.

Alternatively to the attempt to add co-stimulating signals to cell or peptide vaccines, some researchers turned directly to key elements responsible for the formation of adaptive cell immunity, i.e. to dendritic cells. The process for making dendritic cellular vaccines includes the isolation of DC from patient's blood, the induction of their maturation ex vivo and sensibilization either by tumor cell lysate, or by synthetic tumor-specific peptides, recombinant vectors, tumor DNA or RNA. Dendritic cell vaccine loaded with antigens of tumor lysate was shown to be able to cause a marked $\mathrm{T}$ cell tumor-specific response in patients with metastatic colorectal cancer [58-60].

In addition to autologous tumor preparations, allogenic lysates are also used in colon cancer treatment using dendritic cell vaccines $[61,62]$. Since an increased CEA expression is frequently observed in colorectal cancer, dendritic cell vaccines against this tumor are made using CEA peptide, or the CEA-expressing vectors [63, 64]. The most patients of the referent clinical trials demonstrated a marked CEA-specific T cell response, and some patients also demonstrated tumor growth stabilization.

Thus, it may be concluded that the administration of anticancer vaccines to patients with colorectal carcinoma, as a rule, induces marked immune response to a certain antigen, and in some cases it also results in the improvement of survival indices; the examples are given in the review. However, ambitious metastudies of the efficiency of vaccines of different origin in colorectal cancer treatment showed that an induced immune response is rarely accompanied by the survival indices improvement $[65,66]$. Therapeutic vaccines are likely to be more effective as a part of a combined immunotherapy aimed at both immune response stimulation, and elimination of immunosuppressive tumor effect.

\section{Application of cytokines in colon cancer immunotherapy}

Cytokines are biologically active substances, which are the products of immunocompetent cells with autoand paracrine regulatory mechanisms of their activity through specific receptors. All the variety of cytokines is conditionally divided into three main groups: growth (colony-stimulating) factors controlling the production of immunocompetent cells; pro-inflammatory providing mobilization and activation of cells - participants of inflammation, and anti-inflammatory with opposite effects: limiting inflammation development, regulating cellular and humoral immunity. Cytokines also regulate the processes of angiogenesis, regeneration, proliferation, apoptosis, metabolism, etc. [67]. The main cells producing pro-inflammatory cytokines are activated monocytes, macrophages, DC, NK, T lymphocytes; antiinflammatory $-\mathrm{T}$ cells, primarily $\mathrm{CD}^{+} \mathrm{CD}^{+} \mathrm{CD} 8^{-}$(Th1 and Th2). However, cytokines can be produced not only by immunocompetent cells, but also by the cells of a tumor and its microenvironment [68]. Potential high efficiency of therapeutics based on cytokines enables to consider it as a promising field of research in colon cancer immunotherapy.

A significant work was carried out in Rostov Research Institute of Oncology to study the cytokines' ratio of a tumor and non-malignized colon tissue. The tissue content of such cytokines as IL-6, IL-8, IL-1 $\alpha$ and others in colorectal malignant tumor was found to be significantly higher than in the peritumoral area and in the resection margin, as well as in tissue of benign tumor (adenoma) [69, 70]. Tissue cytokine status in primary multiple colorectal cancer, in particular, in metachronic tumors, has some variations from single tumors; differences in the content of some cytokines (TNF- $\alpha$, $\mathrm{IL}-1 \alpha)$ in metachronous and synchronous tumors also involve peritumoral area and a resection margin. The differences found indicate a key role of tissue immune and inflammatory responses in colon cancer pathogenesis.

The data on experimental studies of cytokine application as a part of a combined therapy for colorectal carcinoma seemed to be inspiring [71-74]; however, clinical trials have shown contradictory results. Initially high expectations in colon cancer treatment were related to the use of interferons, since they have a direct and indirect (mediated via immunocompetent cells) antitumor effect: suppression of tumor cell proliferation, induction of their apoptosis, increased of MHC class I molecules expression, stimulation of NK and cytotoxic cells, anti-angiogenic effect [75]. However, longterm clinical trials of interferon therapy capabilities of this oncopathology showed ambiguous results. On the one hand, there has been demonstrated the efficacy of adding IFN- $\alpha$ chemotherapy on colorectal carcinoma cell lines [73, 74]; furthermore, there are evidences in favor of the fact that polymorphism in 
interferon signal pathway genes is associated with high susceptibility to colon cancer [76, 77]. However, clinical trials of combining IFN- $\alpha$ with 5-fluorouracil [78], with 5-fluorouracil and levamisole [79], as well as the combinations with 5-fluorouracil IFN- $\beta$ [80] and IFN- $\gamma$ [81] yielded no favorable results, and showed the toxicity of such combined treatment.

The studies on using IL-2 as a part of a combined therapy in colorectal cancer appeared to be more successful. It causes apoptosis of tumor cells, stimulation of $\mathrm{T}, \mathrm{B}$ and NK lymphocytes and also is able to produce anti-angiogenic effect [75]. The results of recent clinical trials have shown that granulocyte macrophage colony-stimulating factor (GM-CSF) and IL-2 (GOLFIG mode) supplemented to conventional chemotherapy results in an increase of total and progressive-free survival in colon cancer patients [82, 83]. Moreover, the experience of Russian researchers has shown that recombinant IL-2 (Roncoleukin) included in a complex therapy of advanced colorectal cancer enables to reach a positive effect in $77.2 \%$ patients when combined with conventional chemotherapy, as well as results in growth delay of liver metastases and the decrease of their size when the it is combined with regional arterial chemoembolization [84-86].

Generally, the activity of cytokines in vivo is confined by a small area, and has a short period of time; however, their therapeutic application is related to a continuous administration of high doses that can cause adverse reactions due to systemic inflammation [87]. To avoid side effects of the drug and to enhance its efficiency, strategy of local delivery of cytokines into tumor was developed by inserting the genes encoding synthesis of cytokines in recombinant vectors of viral particles or agents of non-viral nature. The first advances were demonstrated in preclinical trials on animal models. The administration of a modified NDV expressing IL-2 resulted in tumor growth inhibition up to total regression in most tumor-bearing mice with a grafted CT26 [88]. The same model was used to demonstrate the more effective (compared to a non-modified virus) reduction of liver metastases when animals are infected with herpes simplex virus of type 1 (HSV-1) expressing IL-2 or GMCSF [89], as well as the enhancement of an anti-tumor immune response in the administration of vesicular stomatitis virus expressing IL-15 [90]. However, it is unknown if there are successful clinical trials on targeted delivery of anticancer cytokines in colorectal carcinoma.

Since many interleukins were found to have both immunomodulatory properties, and growth stimulating activity [91], the presence in adenoma and colorectal carcinoma tissue of IL-6, IL-17A, IL-22, TNF- $\alpha$ and a number of other cytokines, as well as growth factors is considered to provide such key features of tumor cells as apoptosis resistance, abnormal growth and proliferation, genetic instability induction, development of blood vessels, invasion and metastasis [92-95].

Thus, the presence of numerous pro-oncogenic cytokines in colorectal carcinoma tissue implies that both cytokine and anti-cytokine therapy can be suggested to gain more success in tumor treatment. First advances were achieved on experimental models. So, IL-6/STAT3 signal way blocking resulted in a significant decrease of tumor incidence on a murine model associated with chronic colitis oncogenesis [96]. Another trial on a similar model of induced oncogenesis showed the blocking of granulocyte colony stimulating factor (G-CSF) activating growth and migration in colorectal carcinoma culture cells that resulted in reduced incidence of tumor and immune response enhancement [97]. The results of our research [98] showed a positive clinical effect and immune status dynamics when a combined treatment of patients with colorectal cancer included the combinations of Mexidol and Galavit inhibiting an increased synthesis of TNF- $\alpha$, IL-1, IL-6 and other pro-inflammatory cytokines.

A great obstacle on the way of a combined therapy using cytokines and immunotherapy in general, is the effect of chemotherapeutics on immune system activity, which is unclear to a full degree so far. Some of them are able to impair such parameters as number and composition of released tumor antigens and to trigger various transformations of tumor microenvironment, which will influence the immune system behavior producing either stimulation or inactivation of cytokines' effect [99]. Further study development on the interaction of cytokine net with colon tumor tissues and the effect of conventional chemotherapy and the development of new ways to reduce cytokine therapy toxicity, will enable to develop and introduce a great number of new highefficient anti-cancer immune preparations and combined therapy modes in the future.

\section{Adoptive immunotherapy of colon cancer}

A principle of adoptive immunotherapy consists in ex vivo activation of lymphocytes, isolated from patient's blood or tumor tissue, by cytokines with their further administration to the patient. Lymphokine-activated killer (LAK) cells were first used for cancer therapy by Rosenberg and colleagues in the middle of 80 s of the last century [100]. They originate from NK cells of patient's blood; ex vivo IL-2 stimulation causes the enhancement of their cytolytic activity and broadening of a target-cell spectrum; however, they remain innate immunity factors, and have no antigen-specificity. Later on cytokineinduced killer $(\mathrm{CIK})$ cells were obtained. They are circulating lymphocytes, stimulated by INF-y, IL-1, IL-2 and antibodies to CD3, which exhibit the properties of both kinds of killer lymphocytes: NK and T cells providing the recognition of target cells expressing and nonexpressing MHC class I molecules [101].

Tumor infiltrating lymphocytes (TILs) contain various subsets including $\mathrm{T}$ cells, which were in contact with tumor antigens; therefore, some authors consider them to be the best material for cytokine-induced tumorspecific killer cells, the main difficulty being due to 
a limited availability of TILs compared to circulating lymphocytes [102]. The application of cytokine-induced TILs demonstrated a positive effect in the treatment of metastatic melanoma - a tumor exhibiting high immunogenicity compared to other malignancies [103]. To overcome insufficient immunogenicity of other tumors, some researchers tried to modify autologous circulating $T$ lymphocytes providing them with $T$ cell receptors (TCR), which with high specificity to cancer antigen. However, the function of such receptors depends on haplotype of a major histocompatibility complex, and therefore, cannot be used universally. Therefore, chimeric receptors were developed consisting of a heavy chain of monoclonal antibody recognizing the antigen linked to signal intracellular domains initiating cytotoxic reactions typical for $T$ cells [104]. Since antibodies are able to recognize a specific antigen MHC-unlinked class I protein, therapeutics based on T cells with chimeric receptors can be used regardless patients' immunogenetic properties.

Currently, there is no evidence of successful application of LAK in colon cancer therapy. The colorectal carcinoma therapy using cytokine-induced killer cells catches greater interest and the contemporary data indicate potentially high efficiency of using $\mathrm{CIK}$ in combination with conventional chemotherapy [105]. Positive results of a combined immunotherapy, namely, ClK used along with dendritic cell vaccine sensibilized by autologius tumor lysate, as a supplement to conventional postoperative adjuvant chemotherapy in colorectal cancer is also described [106-108]. All researches show immunotherapy included in an anticancer treatment course to result in a significant increase of total survival. Good acceptability of the therapy and improved clinical indices of patients has been demonstrated.

The application of antigen-specific and chimeric receptors for additional modification of autologous circulating $T$ cells in patients with colon cancer has not yet given a significant advantage, and, moreover, not infrequently it was accompanied by marked side effects. The 1st phase of clinical trial of human T cells expressing CEA-specific mouse TCR was carried out [109]. The research results showed all patients to have a significant decrease of circulating CEA level; however, the treatment was accompanied by the development of acute colitis. Serious side effects were also found in metastatic colon cancer when studying a therapeutic effect of $T$ cells expressing Her2-specific chimeric receptor [110].

Thus, the analysis of data gathered showed the necessity to undertake further studies to increase the efficacy and safety of adoptive immunotherapy for colon cancer. Furthermore, the series obstacles in the development of adoptive immunotherapy are still its high labor intensity and high cost.

\section{Conclusion}

Currently, new knowledge on immunotherapy of solid tumors is being intensively accumulated and new promising techniques are being originated. The most advanced are those in the field of searching new immune checkpoints, development of highly efficient the immune adjuvants based on recombinant viruses to enhance the effect of anticancer vaccines, as well as design engineering of T cells' chimeric receptors to improve adoptive cellular therapy by giving it an antigenspecific constituent. However, even now it is clear that the development of any universal immunotherapeutic, which could have been used as monotherapy with high efficiency is unfeasible. Achievements in treating malignancies including colon cancer depends on a combined application of both: recent developments in immunotherapy, and also conventional cures for oncologic diseases - surgical resection of a tumor, the use of cytostatics, radiation, etc. The application of different immunotherapeutic methods in an adjuvant mode to eliminate residual tumor cells implies an antirelapsing effect and the enhancement of total and progressive-free survival of patients. A critical goal is to optimize the selection of immunotherapy variant, as well as its place in combined treatment, which would enable to achieve the potentiation of the effect by means of application of new and known approaches to cancer treatment.

Study Funding. The study was supported by an internal grant of Southern Federal University 213.01-072014/05 PChVG.

Conflicts of Interest. The authors have neither potential nor existing conflicts of interest related to the present study.

\section{References}

1. Burnet M. Cancer - a biological approach: III. Viruses associated with neoplastic conditions. IV. Practical applications. Br Med J 1957; 1(5023): 841-847, https://doi. org/10.1136/bmj.1.5023.841.

2. Thomas L. Delayed hypersensitivity in health and disease. In: Cellular and humoral aspects of the hypersensitive states. Lawrence H.S. (editor). Hoeber-Harper; 1959; p. 529-532.

3. Stutman O. Chemical carcinogenesis in nude mice: comparison between nude mice from homozygous and heterozygous matings and effect of age and carcinogen dose. J Natl Cancer Inst 1979; 2: 353-358, https://doi.org/10.1093/ jnci/62.2.353.

4. Hunig T. T-cell function and specificity in athymic mice. Immunol Today 1983; 4(3): 84-87, https://doi.org/ 10.1016/0167-5699(83)90125-1.

5. Maleckar J.R., Sherman L.A. The composition of the $T$ cell receptor repertoire in nude mice. J Immunol 1987; 138(11): 3873-3876.

6. Shankaran V., Ikeda H., Bruce A.T., White J.M., Swanson P.E., Old L.J., Schreiber R.D. IFNgamma and lymphocytes prevent primary tumour development and shape tumour immunogenicity. Nature 2001; 410(6832): 1107-1111, https://doi.org/10.1038/35074122.

7. Dunn G.P., Bruce A.T., Ikeda H., Old L.J., Schreiber R.D. Cancer immunoediting: from immunosurveillance to tumor 
escape. Nat Immunol 2002; 3(11): 991-998, https://doi. org/10.1038/ni1102-991.

8. Tryakin A.A., Artamonova E.V., Besova N.S., Bolotina L.V., Gladkov O.A., Glebovskaya V.V., et al. Practical guidelines on medical therapy of rectal cancer. Zlokachestvennye opukholi 2015; 4(Special Issue): 230-246.

9. Tryakin A.A., Artamonova E.V., Besova N.S., Bolotina L.V., Vladimirova L.Yu., Gladkov O.A., et al. Practical guidelines on medical therapy of colon cancer. Zlokachestvennye opukholi 2015; 4(Special Issue): 214-229.

10. Grothey A., Flick E.D., Cohn A.L., Bekaii-Saab T.S., Bendell J.C., Kozloff M., Roach N., Mun Y., Fish S., Hurwitz H.I. Bevacizumab exposure beyond first disease progression in patients with metastatic colorectal cancer: analyses of the ARIES observational cohort study. Pharmacoepidemiol Drug Saf 2014; 23(7): 726-734, https://doi.org/10.1002/pds.3633.

11. Hurwitz H.I., Tebbutt N.C., Kabbinavar F., Giantonio B.J., Guan Z.Z., Mitchell L., Waterkamp D., Tabernero J. Efficacy and safety of bevacizumab in metastatic colorectal cancer: pooled analysis from seven randomized controlled trials. Oncologist 2013; 18(9): 1004-1012, https:// doi.org/10.1634/theoncologist.2013-0107.

12. Price T.J., Peeters M., Kim T.W., Li J., Cascinu S., Ruff P., Suresh A.S., Thomas A., Tjulandin S., Zhang K., Murugappan S., Sidhu R. Panitumumab versus cetuximab in patients with chemotherapy-refractory wild-type KRAS exon 2 metastatic colorectal cancer (ASPECCT): a randomised, multicentre, open-label, non-inferiority phase 3 study. Lancet Oncol 2014; 15: 569-579, https://doi.org/10.1016/s14702045(14)70118-4.

13. Van Cutsem E., Köhne C.H., Láng I., Folprecht G., Nowacki M.P., Cascinu S., Shchepotin I., Maurel J., Cunningham D., Tejpar S., Schlichting M., Zubel A., Celik I., Rougier P., Ciardiello F. Cetuximab plus irinotecan, fluorouracil, and leucovorin as first-line treatment for metastatic colorectal cancer: updated analysis of overall survival according to tumor KRAS and BRAF mutation status. J Clin Oncol 2011; 29(15): 2011-2019, https://doi.org/10.1200/ jco.2010.33.5091.

14. Vacchelli E., Aranda F., Eggermont A., Galon J., SautèsFridman C., Zitvogel L., Kroemer G., Galluzzi L. Trial Watch: Tumor-targeting monoclonal antibodies in cancer therapy. Oncoimmunology 2014; 3(1): e27048, https://doi.org/10.4161/ onci.27048.

15. Yang X., Zhang X., Mortenson E.D., RadkevichBrown O., Wang Y., Fu Y.X. Cetuximab-mediated tumor regression depends on innate and adaptive immune responses. Mol Ther 2013; 21(1): 91-100, https://doi. org/10.1038/mt.2012.184.

16. Kohrt H.E., Colevas A.D., Houot R., Weiskopf K., Goldstein M.J., Lund P., Mueller A., Sagiv-Barfi I., Marabelle A., Lira R., Troutner E., Richards L., Rajapaska A., Hebb J., Chester C., Waller E., Ostashko A., Weng W.K., Chen L., Czerwinski D., Fu Y.X., Sunwoo J., Levy R. Targeting CD137 enhances the efficacy of cetuximab. J Clin Invest 2014; 124(6): 2668-2682, https://doi.org/10.1172/jci73014.

17. Calemma R., Ottaiano A., Trotta A.M., Nasti G., Romano C., Napolitano M., Galati D., Borrelli P., Zanotta S., Cassata A., Castello G., laffaioli V.R., Scala S. Fc gamma receptor IIla polymorphisms in advanced colorectal cancer patients correlated with response to anti-EGFR antibodies and clinical outcome. J Transl Med 2012; 10: 232, https://doi. org/10.1186/1479-5876-10-232.
18. Rodríguez J., Zarate R., Bandres E., Boni V., Hernández A., Sola J.J., Honorato B., Bitarte N., GarcíaFoncillas J. Fc gamma receptor polymorphisms as predictive markers of cetuximab efficacy in epidermal growth factor receptor downstream-mutated metastatic colorectal cancer. Eur J Cancer 2012; 48(12): 1774-1780, https://doi. org/10.1016/j.ejca.2012.01.007.

19. Riethmüller G., Schneider-Gädicke E., Schlimok G., Schmiegel W., Raab R., Höffken K., Gruber R., Pichlmaier H., Hirche H., Pichlmayr R., Witte J. Randomised trial of monoclonal antibody for adjuvant therapy of resected Dukes' C colorectal carcinoma. German Cancer Aid 17-1A Study Group. Lancet 1994; 343(8907): 1177-1183, https://doi.org/10.1016/ s0140-6736(94)92398-1.

20. Punt C.J., Nagy A., Douillard J.Y., Figer A., Skovsgaard T., Monson J., Barone C., Fountzilas G., Riess H., Moylan E., Jones D., Dethling J., Colman J., Coward L., MacGregor S. Edrecolomab alone or in combination with fluorouracil and folinic acid in the adjuvant treatment of stage III colon cancer: a randomised study. Lancet 2002; 360(9334): 671-677, https://doi.org/10.1016/ s0140-6736(02)09836-7.

21. Han H., Ma J., Zhang K., Li W., Liu C., Zhang Y., Zhang G., Ma P., Wang L., Zhang G., Tao H., Gao B. Bispecific anti-CD3 $x$ anti-HER2 antibody mediates $T$ cell cytolytic activity to HER2-positive colorectal cancer in vitro and in vivo. Int $J$ Oncol 2014; 45(6): 2446-2454, https://doi.org/10.3892/ ijo.2014.2663.

22. Schmohl J.U., Gleason M.K., Dougherty P.R., Miller J.S., Vallera D.A. Heterodimeric bispecific single chain variable fragments (scFv) killer engagers (BiKEs) enhance NKcell activity against $\mathrm{CD}_{133^{+}}$colorectal cancer cells. Target Oncol 2015; 11(3): 353-361, https://doi.org/10.1007/s11523-0150391-8.

23. Raulet D.H., Gasser S., Gowen B.G., Deng W., Jung H. Regulation of ligands for the NKG2D activating receptor. Annu Rev Immunol 2013; 31: 413-441, https://doi.org/10.1146/ annurev-immunol-032712-095951.

24. Wu A.A., Drake V., Huang H.S., Chiu S., Zheng L. Reprogramming the tumor microenvironment: tumor-induced immunosuppressive factors paralyze T cells. Oncoimmunology 2015; 4(7): e1016700, https://doi.org/10.1080/216240 2x.2015.1016700.

25. Rothe A., Jachimowicz R.D., Borchmann S., Madlener M., Keßler J., Reiners K.S., Sauer M., Hansen H.P., Ullrich R.T., Chatterjee S., Borchmann P., Yazaki P., Koslowsky T.C., Engert A., Heukamp L.C., Hallek M., von Strandmann E.P. The bispecific immunoligand ULBP2-aCEA redirects natural killer cells to tumor cells and reveals potent anti-tumor activity against colon carcinoma. Int J Cancer 2014; 134(12): 2829-2840, https://doi.org/10.1002/ijc.28609.

26. Kadagidze Z.G., Slavina E.G., Chertkova A.I. Lymphocyte receptors that regulate the immune response the key to the management of antitumor immunity. Voprosy onkologii 2015; 61(4): 523-529.

27. Walunas T.L., Lenschow D.J., Bakker C.Y., Linsley P.S., Freeman G.J., Green J.M., Thompson C.B., Bluestone J.A. CTLA- 4 can function as a negative regulator of $T$ cell activation. Immunity 1994; 1(5): 405-413, https://doi.org/10.1016/10747613(94)90071-x.

28. Freeman G.J., Long A.J., Iwai Y., Bourque K., Chernova T., Nishimura H., Fitz L.J., Malenkovich N., Okazaki T., Byrne M.C., Horton H.F., Fouser L., Carter L., 
Ling V., Bowman M.R., Carreno B.M., Collins M., Wood C.R., Honjo T. Engagement of the PD-1 immunoinhibitory receptor by a novel $B 7$ family member leads to negative regulation of lymphocyte activation. J Exp Med 2000; 192(7): 1027-1034, https://doi.org/10.1084/jem.192.7.1027.

29. Dong H., Strome S.E., Salomao D.R., Tamura H., Hirano F., Flies D.B., Roche P.C., Lu J., Zhu G., Tamada K., Lennon V.A., Celis E., Chen L. Tumor-associated B7-H1 promotes T-cell apoptosis: a potential mechanism of immune evasion. Nat Med 2002; 8(8): 793-800, https://doi.org/10.1038/ nm730.

30. Brahmer J.R., Tykodi S.S., Chow L.Q., Hwu W.J., Topalian S.L., Hwu P., Drake C.G., Camacho L.H., Kauh J., Odunsi K., Pitot H.C., Hamid O., Bhatia S., Martins R., Eaton K., Chen S., Salay T.M., Alaparthy S., Grosso J.F., Korman A.J., Parker S.M., Agrawal S., Goldberg S.M., Pardoll D.M., Gupta A., Wigginton J.M. Safety and activity of anti-PD-L1 antibody in patients with advanced cancer. N Engl J Med 2012; 366(26): 2455-2465, https://doi.org/10.1056/nejmoa1200694.

31. Hodi F.S., O'Day S.J., McDermott D.F., Weber R.W., Sosman J.A., Haanen J.B., Gonzalez R., Robert C., Schadendorf D., Hassel J.C., Akerley W., van den Eertwegh A.J., Lutzky J., Lorigan P., Vaubel J.M., Linette G.P., Hogg D., Ottensmeier C.H., Lebbé C., Peschel C., Quirt I., Clark J.I., Wolchok J.D., Weber J.S., Tian J., Yellin M.J., Nichol G.M., Hoos A., Urba W.J. Improved survival with ipilimumab in patients with metastatic melanoma. $N$ Engl $J$ Med 2010; 363(8): 711-723, https://doi.org/10.1056/ nejmoa1003466.

32. Topalian S.L., Hodi F.S., Brahmer J.R., Gettinger S.N., Smith D.C., McDermott D.F., Powderly J.D., Carvajal R.D., Sosman J.A., Atkins M.B., Leming P.D., Spigel D.R., Antonia S.J., Horn L., Drake C.G., Pardoll D.M., Chen L., Sharfman W.H., Anders R.A., Taube J.M., McMiller T.L., Xu H., Korman A.J., Jure-Kunkel M., Agrawal S., McDonald D., Kollia G.D., Gupta A., Wigginton J.M., Sznol M. Safety, activity, and immune correlates of anti-PD-1 antibody in cancer. $N$ Engl J Med 2012; 366(26): 2443-2454, https://doi.org/10.1056/ nejmoa1200690.

33. Wolchok J.D., Kluger H., Callahan M.K., Postow M.A., Rizvi N.A., Lesokhin A.M., Segal N.H., Ariyan C.E., Gordon R.A., Reed K., Burke M.M., Caldwell A., Kronenberg S.A., Agunwamba B.U., Zhang X., Lowy I., Inzunza H.D., Feely W., Horak C.E., Hong Q., Korman A.J., Wigginton J.M., Gupta A., Sznol M. Nivolumab plus ipilimumab in advanced melanoma. N Engl J Med 2013; 369(2): 122-133, https://doi.org/10.1056/nejmoa1302369.

34. Ge J., Zhu L., Zhou J., Li G., Li Y., Li S., Wu Z., Rong J., Yuan H., Liu Y., Chi Q., Piao D., Zhao Y., Cui B. Association between co-inhibitory molecule gene tagging single nucleotide polymorphisms and the risk of colorectal cancer in Chinese. J Cancer Res Clin Oncol 2015; 141(9): 1533-1544, https://doi. org/10.1007/s00432-015-1915-4.

35. Mojtahedi Z., Mohmedi M., Rahimifar S., Erfani N., Hosseini S.V., Ghaderi A. Programmed death-1 gene polymorphism (PD-1.5 C/T) is associated with colon cancer. Gene 2012; 508(2): 229-232, https://doi.org/10.1016/j. gene.2012.07.059.

36. Hua D., Sun J., Mao Y., Chen L.J., Wu Y.Y., Zhang X.G. B7-H1 expression is associated with expansion of regulatory T cells in colorectal carcinoma. World J Gastroenterol 2012; 18(9): 971-978, https://doi.org/10.3748/wjg.v18.i9.971.

37. Droeser R.A., Hirt C., Viehl C.T., Frey D.M., Nebiker C.,
Huber X., Zlobec I., Eppenberger-Castori S., Tzankov A., Rosso R., Zuber M., Muraro M.G., Amicarella F., Cremonesi E., Heberer M., lezzi G., Lugli A., Terracciano L., Sconocchia G., Oertli D., Spagnoli G.C., Tornillo L. Clinical impact of programmed cell death ligand 1 expression in colorectal cancer. Eur J Cancer 2013; 49(9): 2233-2242, https://doi. org/10.1016/j.ejca.2013.02.015.

38. Le D.T., Uram J.N., Wang H., Bartlett B.R., Kemberling H., Eyring A.D., Skora A.D., Luber B.S., Azad N.S., Laheru D., Biedrzycki B., Donehower R.C., Zaheer A., Fisher G.A., Crocenzi T.S., Lee J.J., Duffy S.M., Goldberg R.M., de la Chapelle A., Koshiji M., Bhaijee F., Huebner T., Hruban R.H., Wood L.D., Cuka N., Pardoll D.M., Papadopoulos N., Kinzler K.W., Zhou S., Cornish T.C., Taube J.M., Anders R.A., Eshleman J.R., Vogelstein B., Diaz L.A. Jr.PD-1 blockade in tumors with mismatch-repair deficiency. N Engl J Med 2015; 372(26): 2509-2520, https:// doi.org/10.1056/nejmoa1500596.

39. Chung K.Y., Gore I., Fong L., Venook A., Beck S.B., Dorazio P., Criscitiello P.J., Healey D.I., Huang B., GomezNavarro J., Saltz L.B. Phase II study of the anti-cytotoxic T-lymphocyte-associated antigen 4 monoclonal antibody, tremelimumab, in patients with refractory metastatic colorectal cancer. J Clin Oncol 2010; 28(21): 3485-3490, https://doi. org/10.1200/jco.2010.28.3994.

40. Xu B., Yuan L., Gao Q., Yuan P., Zhao P., Yuan H., Fan H., Li T., Qin P., Han L., Fang W., Suo Z. Circulating and tumor-infiltrating Tim-3 in patients with colorectal cancer. Oncotarget 2015; 6(24): 20592-20603, https://doi. org/10.18632/oncotarget.4112.

41. Chen J., Chen Z. The effect of immune microenvironment on the progression and prognosis of colorectal cancer. Med Oncol 2014; 31(8): 82, https://doi. org/10.1007/s12032-014-0082-9.

42. Weixler B., Cremonesi E., Sorge R., Muraro M.G., Delko T., Nebiker C.A., Däster S., Governa V., Amicarella F., Soysal S.D., Kettelhack C., von Holzen U.W., EppenbergerCastori S., Spagnoli G.C., Oertli D., lezzi G., Terracciano L., Tornillo L., Sconocchia G., Droeser R.A. OX40 expression enhances the prognostic significance of CD8 positive lymphocyte infiltration in colorectal cancer. Oncotarget 2015; 6(35): 37588-37599, https://doi.org/10.18632/oncotarget.5940.

43. Keenan B.P., Jaffee E.M. Whole cell vaccines - past progress and future strategies. Semin Oncol 2012; 39(3): 276286, https://doi.org/10.1053/j.seminoncol.2012.02.007.

44. Schulze T., Kemmner W., Weitz J., Wernecke K.D., Schirrmacher V., Schlag P.M. Efficiency of adjuvant active specific immunization with Newcastle disease virus modified tumor cells in colorectal cancer patients following resection of liver metastases: results of a prospective randomized trial. Cancer Immunol Immunother 2009; 58(1): 61-69, https://doi. org/10.1007/s00262-008-0526-1.

45. Becerra A.Z., Probst C.P., Tejani M.A., Aquina C.T., González M.G., Hensley B.J., Noyes K., Monson J.R., Fleming F.J. Evaluating the prognostic role of elevated preoperative carcinoembryonic antigen levels in colon cancer patients: results from the national cancer database. Ann Surg Oncol 2016; 23(5): 1554-1561, https://doi.org/10.1245/ s10434-015-5014-1.

46. Duncan T.J., Watson N.F., Al-Attar A.H., Scholefield J.H., Durrant L.G. The role of MUC1 and MUC3 in the biology and prognosis of colorectal cancer. World J Surg Oncol 2007; 5: 31, https://doi.org/10.1186/1477-7819-5-31. 
47. Lundin M., Nordling S., Lundin J., Alfthan $H$., Stenman U.H., Haglund C. Tissue expression of human chorionic gonadotropin beta predicts outcome in colorectal cancer: a comparison with serum expression. Int $J$ Cancer 2001; 95(1): 18-22, https://doi.org/10.1002/10970215(20010120)95:1<18::aid-ijc1003>3.0.co;2-5.

48. Kawasaki H., Altieri D.C., Lu C.D., Toyoda M., Tenjo T., Tanigawa N. Inhibition of apoptosis by survivin predicts shorter survival rates in colorectal cancer. Cancer Res 1998; 58(22): 5071-5074.

49. Saito T., Masuda N., Miyazaki T., Kanoh K., Suzuki H., Shimura T., Asao T., Kuwano H. Expression of EphA2 and E-cadherin in colorectal cancer: correlation with cancer metastasis. Oncol Rep 2004; 11(3): 605-611, https://doi. org/10.3892/or.11.3.605.

50. Sasatomi T., Suefuji Y., Matsunaga K., Yamana H., Miyagi Y., Araki Y., Ogata Y., Itoh K., Shirouzu K. Expression of tumor rejection antigens in colorectal carcinomas. Cancer 2002; 94(6): 1636-1641, https://doi.org/10.1002/cncr.10421.

51. Moulton H.M., Yoshihara P.H., Mason D.H., Iversen P.L., Triozzi P.L. Active specific immunotherapy with a beta-human chorionic gonadotropin peptide vaccine in patients with metastatic colorectal cancer: antibody response is associated with improved survival. Clin Cancer Res 2002; 8(7): 2044-2051.

52. Mukherjee P., Pathangey L.B., Bradley J.B., Tinder T.L., Basu G.D., Akporiaye E.T., Gendler S.J. MUC1-specific immune therapy generates a strong anti-tumor response in a MUC1-tolerant colon cancer model. Vaccine 2007; 25(9): 1607-1618, https://doi.org/10.1016/j.vaccine.2006.11.007.

53. Kimura T., McKolanis J.R., Dzubinski L.A., Islam K., Potter D.M., Salazar A.M., Schoen R.E., Finn O.J. MUC1 vaccine for individuals with advanced adenoma of the colon: a cancer immunoprevention feasibility study. Cancer Prev Res (Phila) 2013; 6(1): 18-26, https://doi.org/10.1158/1940-6207. capr-12-0275.

54. Hörig H., Lee D.S., Conkright W., Divito J., Hasson H., LaMare M., Rivera A., Park D., Tine J., Guito K., Tsang K.W., Schlom J., Kaufman H.L. Phase I clinical trial of a recombinant canarypoxvirus (ALVAC) vaccine expressing human carcinoembryonic antigen and the B7.1 co-stimulatory molecule. Cancer Immunol Immunother 2000; 49(9): 504-514, https://doi.org/10.1007/s002620000146.

55. Kaufman H.L., Lenz H.J., Marshall J., Singh D., Garett C., Cripps C., Moore M., von Mehren M., Dalfen R., Heim W.J., Conry R.M., Urba W.J., Benson A.B. 3rd, Yu M., Caterini J., Kim-Schulze S., Debenedette M., Salha D., Vogel T., Elias I., Berinstein N.L. Combination chemotherapy and ALVAC-CEA/B7.1 vaccine in patients with metastatic colorectal cancer. Clin Cancer Res 2008; 14(15): 4843-4849, https://doi.org/10.1158/1078-0432.ccr-08-0276.

56. Gameiro S.R., Higgins J.P., Dreher M.R., Woods D.L., Reddy G., Wood B.J., Guha C., Hodge J.W. Combination therapy with local radiofrequency ablation and systemic vaccine enhances antitumor immunity and mediates local and distal tumor regression. PLoS One 2013; 8(7): e70417, https:// doi.org/10.1371/journal.pone.0070417.

57. Gulley J.L., Madan R.A., Tsang K.Y., Arlen P.M., Camphausen K., Mohebtash M., Kamrava M., Schlom J., Citrin D. A pilot safety trial investigating a vector-based vaccine targeting carcinoembryonic antigen in combination with radiotherapy in patients with gastrointestinal malignancies metastatic to the liver. Expert Opin Biol Ther 2011; 11(11): 1409-1418, https://doi.org/10.1517/14712598.2011.615741.
58. Liu Y., Zhang W., Zhang B., Yin X., Pang Y. DC vaccine therapy combined concurrently with oral capecitabine in metastatic colorectal cancer patients. Hepatogastroenterology 2013; 60(121): 23-27.

59. Tamir A., Basagila E., Kagahzian A., Jiao L., Jensen S., Nicholls J., Tate P., Stamp G., Farzaneh F., Harrison P., Stauss H., George A.J., Habib N., Lechler R.I., Lombardi G. Induction of tumor-specific $T$ cell responses by vaccination with tumor lysate-loaded dendritic cells in colorectal cancer patients with carcinoembryonic-antigen positive tumors. Cancer Immunol Immunother 2007; 56(12): 2003-2016, https://doi. org/10.1007/s00262-007-0299-y.

60. Wu Y.G., Wu G.Z., Wang L., Zhang Y.Y., Li Z., Li D.C. Tumor cell lysate-pulsed dendritic cells induce a $T$ cell response against colon cancer in vitro and in vivo. Med Oncol 2010; 27(3): 736-742, https://doi.org/10.1007/s12032-009-9277-x.

61. Burgdorf S.K., Fischer A., Myschetzky P.S., Munksgaard S.B., Zocca M.B., Claesson M.H., Rosenberg J. Clinical responses in patients with advanced colorectal cancer to a dendritic cell based vaccine. Oncol Rep 2008; 20(6): 1305-1311, https://doi.org/10.3892/or_00000145.

62. Toh H.C., Wang W.W., Chia W.K., Kvistborg P., Sun L., Teo K., Phoon Y.P., Soe Y., Tan S.H., Hee S.W., Foo K.F., Ong S., Koo W.H., Zocca M.B., Claesson M.H. Clinical benefit of allogeneic melanoma cell lysate-pulsed autologous dendritic cell vaccine in MAGE-positive colorectal cancer patients Clin Cancer Res 2009; 15(24): 7726-7736, https://doi. org/10.1158/1078-0432.ccr-09-1537.

63. Lesterhuis W.J., de Vries I.J., Schuurhuis D.H., Boullart A.C., Jacobs J.F., de Boer A.J., Scharenborg N.M., Brouwer H.M., van de Rakt M.W., Figdor C.G., Ruers T.J., Adema G.J., Punt C.J. Vaccination of colorectal cancer patients with CEA-loaded dendritic cells: antigen-specific T cell responses in DTH skin tests. Ann Oncol 2006; 17(6): 974-980, https://doi.org/10.1093/annonc/mdl072.

64. Morse M.A., Niedzwiecki D., Marshall J.L., Garrett C., Chang D.Z., Aklilu M., Crocenzi T.S., Cole D.J., Dessureault S., Hobeika A.C., Osada T., Onaitis M., Clary B.M., Hsu D., Devi G.R., Bulusu A., Annechiarico R.P., Chadaram V., Clay T.M., Lyerly H.K. A randomized phase II study of immunization with dendritic cells modified with poxvectors encoding CEA and MUC1 compared with the same poxvectors plus GM-CSF for resected metastatic colorectal cancer. Ann Surg 2013; 258(6): 879-886, https://doi.org/10.1097/sla.0b013e318292919e.

65. Nagorsen D., Thiel E. Clinical and immunologic responses to active specific cancer vaccines in human colorectal cancer. Clin Cancer Res 2006; 12(10): 3064-3069, https://doi.org/10.1158/1078-0432.ccr-05-2788.

66. Rao B., Han M., Wang L., Gao X., Huang J., Huang M., Liu H., Wang J. Clinical outcomes of active specific immunotherapy in advanced colorectal cancer and suspected minimal residual colorectal cancer: a meta-analysis and system review. J Trans/ Med 2011; 9: 17, https://doi.org/10.1186/14795876-9-17.

67. Simbirtsev A.S. Cytokines in allergy immunopathogenesis and therapy. Rossiyskiy allergologicheskiy zhurnal 2007; 1: 5-19.

68. McAllister S.S., Weinberg R.A. The tumour-induced systemic environment as a critical regulator of cancer progression and metastasis. Nat Cell Biol 2014; 16(8): 717727, https://doi.org/10.1038/ncb3015.

69. Zlatnik E.Y., Nikipelova E.A., Terpugov A.L., Maksimov A.Y., Selyutina O.N., Zakora G.I. Cytokine content 
of colorectal polypous tissue. Fundamental'nye issledovaniya 2014; 5-5: 1016-1020.

70. Kit O.I., Zlatnik E.Yu., Nikipelova E.A., Shaposhnikov A.V., Zakora G.I. Comparative characteristics of cytokines' levels in tissues of gut adenoma and adenocarcinoma. Tsitokiny i vospalenie 2012; 11(3): 100-104.

71. Gou H.F., Huang J., Shi H.S., Chen X.C., Wang Y.S. Chemo-immunotherapy with oxaliplatin and interleukin-7 inhibits colon cancer metastasis in mice. PloS One 2014; 9(1): e85789, https://doi.org/10.1371/journal.pone.0085789.

72. Lu L., Li Z.J., Li L.F., Wu W.K., Shen J., Zhang L., Chan R.L., Yu L., Liu Y.W., Ren S.X., Chan K.M., Cho C.H. Vascular-targeted TNFa improves tumor blood vessel function and enhances antitumor immunity and chemotherapy in colorectal cancer. J Control Release 2015; 210: 134-146, https://doi.org/10.1016/j.jconrel.2015.05.282.

73. Yang J.L., Qu X.J., Russell P.J., Goldstein D. Interferonalpha promotes the anti-proliferative effect of erlotinib (OSI774) on human colon cancer cell lines. Cancer Lett 2005; 225(1): 61-74, https://doi.org/10.1016/j.canlet.2004.11.041.

74. Yang J.L., Qu X.J., Russell P.J., Goldstein D. Interferonalpha promotes the anti-proliferative effect of gefitinib (ZD 1839) on human colon cancer cell lines. Oncology 2005; 69(3): 224-238, https://doi.org/10.1159/000088070.

75. Slattery M.L., Lundgreen A., Bondurant K.L., Wolff R.K. Interferon-signaling pathway: associations with colon and rectal cancer risk and subsequent survival. Carcinogenesis 2011; 32(11): 1660-1667, https://doi.org/10.1093/carcin/ bgr189.

76. Molchanov O.E., Karelin M.I., Zharinov G. Current trends of recombinant interleukin 2 application in oncology. Tsitokiny $i$ vospalenie 2002; 1(3): 38-47.

77. Lu S., Pardini B., Cheng B., Naccarati A., Huhn S., Vymetalkova V., Vodickova L., Buchler T., Hemminki K., Vodicka P., Försti A. Single nucleotide polymorphisms within interferon signaling pathway genes are associated with colorectal cancer susceptibility and survival. PLoS One 2014; 9(10): e111061, https://doi.org/10.1371/journal.pone.0111061.

78. Kjaer M. Combining 5-fluorouracil with interferon-alpha in the treatment of advanced colorectal cancer: optimism followed by disappointment. Anticancer Drugs 1996; 7: 35-42, https://doi.org/10.1097/00001813-199601000-00003.

79. Link K.H., Kornmann M., Staib L., Redenbacher M., Kron M., Beger H.G.; Study Group Oncology of Gastrointestinal Tumors. Increase of survival benefit in advanced resectable colon cancer by extent of adjuvant treatment: results of a randomized trial comparing modulation of $5-\mathrm{FU}+$ levamisole with folinic acid or with interferon-alpha. Ann Surg 2005; 242(2): 178-187, https://doi.org/10.1097/01.sla.0000171033.65639.a9.

80. Joffe J.K., Perren T.J., Bradley C., Primrose J., Hallam S., Ward U., Illingworth J.M., Selby P.J. A phase II study of recombinant interferon-beta ( $r$-hIFN-beta 1a) in combination with 5-fluorouracil (5-FU) in the treatment of patients with advanced colorectal carcinoma. Br J Cancer 1997; 75: 423426, https://doi.org/10.1038/bjc.1997.69.

81. Pavlidis N., Nicolaides C., Athanassiadis A., Beriatou K., Skarlos D., Giannakakis T., Kosmidis P., Karvounis N., Fountzilas G. Phase II study of 5-fluorouracil and interferongamma in patients with metastatic colorectal cancer. A Hellenic Cooperative Oncology Group Study. Oncology 1996; 53(2): 159-162.

82. Correale P., Tagliaferri P., Fioravanti A., Del Vecchio M.T., Remondo C., Montagnani F.,
Rotundo M.S., Ginanneschi C., Martellucci I., Francini E., Cusi M.G., Tassone P., Francini G. Immunity feedback and clinical outcome in colon cancer patients undergoing chemoimmunotherapy with gemcitabine + FOLFOX followed by subcutaneous granulocyte macrophage colony-stimulating factor and aldesleukin (GOLFIG-1 Trial). Clin Cancer Res 2008; 14(13): 4192-4199, https://doi.org/10.1158/1078-0432. ccr-07-5278.

83. Correale P., Botta C., Rotundo M.S., Guglielmo A., Conca R., Licchetta A., Pastina P., Bestoso E., Ciliberto D., Cusi M.G., Fioravanti A., Guidelli G.M., Bianco M.T., Misso G., Martino E., Caraglia M., Tassone P., Mini E., Mantovani G., Ridolfi R., Pirtoli L., Tagliaferri P. Gemcitabine, oxaliplatin, levofolinate, 5-fluorouracil, granulocyte-macrophage colonystimulating factor, and interleukin-2 (GOLFIG) versus FOLFOX chemotherapy in metastatic colorectal cancer patients: the GOLFIG-2 multicentric open-label randomized phase III trial. J Immunother 2014; 37(1): 26-35, https://doi.org/10.1097/ cji.0000000000000004.

84. Goloshchapov R.S., Kokov L.S., Vishnevskiy V.A., Ionkin D.A., Elagina L.V. Regional arterial chemoembolization and chemoimmunoembolization in complex treatment of colon cancer with liver metastases. Khirurgiya 2003; 7: 66-71.

85. Promzeleva N.V., Promzelev E.G., Shorokhova T.A., Dem'yanov V.S., Morozov V.P. Opyt primeneniya ronkoleykina - rekombinantnogo interleykina-2 - v khimioimmunoterapii rasprostranennogo kolorektal'nogo raka. $\mathrm{V}$ kn.: Materialy mezhregional'noy nauchno-prakticheskoy konferentsii "Kombinirovannye i kompleksnye metody lecheniya $v$ onkologii" [Experience of Roncoleukin - recombinant interleukin-2 - application in chemoimmunotherapy of advanced colorectal cancer. In: Proceedings of interregional research and practice conference "Combined and complex treatment modalities in oncology"]. Barnaul; 2004; p. 106-109.

86. Stupakova S.V., Teterin A.V. Regionarnaya vnutriarterial'naya khimioimmunoterapiya bol'nykh s metastazami kolorektal'nogo raka pecheni. $\mathrm{V}$ kn.: Materialy konferentsii "Sovremennye tekhnologii diagnostiki $i$ lecheniya zlokachestvennykh opukholey" [Regional intraarterial chemoimmunotherapy of patients with liver metastases in colorectal cancer. In: Proceedings of the conference "Modern diagnostic and treatment technologies for malignant tumors"]. Saint Petersburg; 2005.

87. Simbirtsev A.S. Achievements and perspectives of the recombinant cytokine therapy in clinical practice. Meditsinskiy akademicheskiy zhurnal 2013; 13(1): 7-22.

88. Vigil A., Park M.S., Martinez O., Chua M.A., Xiao S., Cros J.F., Martínez-Sobrido L., Woo S.L., García-Sastre A. Use of reverse genetics to enhance the oncolytic properties of Newcastle disease virus. Cancer Res 2007; 67(17): 82858292, https://doi.org/10.1158/0008-5472.can-07-1025.

89. Derubertis B.G., Stiles B.M., Bhargava A., Gusani N.J., Hezel M., D'Angelica M., Fong Y. Cytokine-secreting herpes viral mutants effectively treat tumor in a murine metastatic colorectal liver model by oncolytic and T-cell-dependent mechanisms. Cancer Gene Ther 2007; 14(6): 590-597, https:// doi.org/10.1038/sj.cgt.7701053.

90. Stephenson K.B., Barra N.G., Davies E., Ashkar A.A., Lichty B.D. Expressing human interleukin-15 from oncolytic vesicular stomatitis virus improves survival in a murine metastatic colon adenocarcinoma model through the enhancement of anti-tumor immunity. Cancer Gene Ther 2012; 19(4): 238-246, https://doi.org/10.1038/cgt.2011.81. 
91. Berezhnaya N.M., Chekhun V.F. Immunologiya zlokachestvennogo rosta [Malignant growth immunology]. Kiev: Naukova dumka; 2005; 792 p.

92. Balkwill F. Tumour necrosis factor and cancer. Nat Rev Cancer 2009; 9(5): 361-371, https://doi.org/10.1038/nrc2628.

93. Cui G., Yuan A., Goll R., Florholmen J. IL-17A in the tumor microenvironment of the human colorectal adenomacarcinoma sequence. Scand J Gastroenterol 2012; 47(11): 1304-1312, https://doi.org/10.3109/00365521.2012.725089.

94. Kryczek I., Lin Y., Nagarsheth N., Peng D., Zhao L., Zhao E., Vatan L., Szeliga W., Dou Y., Owens S., Zgodzinski W., Majewski M., Wallner G., Fang J., Huang E., Zou W. IL-22(+)CD4(+) T cells promote colorectal cancer stemness via STAT3 transcription factor activation and induction of the methyltransferase DOT1L. Immunity 2014; 40(5): 772-784, https://doi.org/10.1016/j. immuni.2014.03.010.

95. Taniguchi K., Karin M. IL-6 and related cytokines as the critical lynchpins between inflammation and cancer. Semin Immunol 2014; 26(1): 54-74, https://doi.org/10.1016/j. smim.2014.01.001.

96. Dai Y., Jiao H., Teng G., Wang W., Zhang R., Wang Y., Hebbard L., George J., Qiao L. Embelin reduces colitisassociated tumorigenesis through limiting IL-6/STAT3 signaling. Mol Cancer Ther 2014; 13(5): 1206-1216, https:// doi.org/10.1158/1535-7163.mct-13-0378.

97. Morris K.T., Castillo E.F., Ray A.L., Weston L.L., Nofchissey R.A., Hanson J.A., Samedi V.G., Pinchuk I.V., Hudson L.G., Beswick E.J. Anti-G-CSF treatment induces protective tumor immunity in mouse colon cancer by promoting protective NK cell, macrophage and $\mathrm{T}$ cell responses. Oncotarget 2015; 6(26): 22338-22347, https://doi. org/10.18632/oncotarget.4169.

98. Kit O.I., Nabatova O.S., Zlatnik E.Y., Pavlenko S.G., Nistratova O.V. Dynamics of some parameters of cellmediated ular immunity in patients with colorectal cancer in complex treatment by immunomodulators and antioxidants. Fundamental'nye issledovaniya 2014; 7-2: 286-289.

99. Lake R.A., Robinson B.W. Immunotherapy and chemotherapy - a practical partnership. Nat Rev Cancer 2005; 5(5): 397-405, https://doi.org/10.1038/nrc1613.

100. Rosenberg S.A., Lotze M.T., Muul L.M., Leitman S., Chang A.E., Vetto J.T., Seipp C.A., Simpson C. A new approach to the therapy of cancer based on the systemic administration of autologous lymphokine-activated killer cells and recombinant interleukin-2. Surgery 1986; 100(2): 262-272.

101. Schmidt-Wolf I.G., Negrin R.S., Kiem H.P., Blume K.G. Weissman I.L. Use of a SCID mouse/human lymphoma model to evaluate cytokine-induced killer cells with potent antitumor cell activity. \ Exp Med 1991; 174(1): 139149, https://doi.org/10.1084/jem. 174.1.139.

102. Davydov M.I. Orazgel'dyev K.R., Volkov S.M.,
Kiselevskiy M.V. Adoptivnaya immunoterapiya opukholevykh plevritov. V kn.: Novoe $v$ onkologii [Adoptive immunotherapy of tumor pleurites. In: New advances in incology]. Moscow; 2001; p. $75-78$.

103. Rosenberg S.A., Yang J.C., Sherry R.M., Kammula U.S., Hughes M.S., Phan G.Q., Citrin D.E., Restifo N.P., Robbins P.F., Wunderlich J.R., Morton K.E., Laurencot C.M., Steinberg S.M., White D.E., Dudley M.E. Durable complete responses in heavily pretreated patients with metastatic melanoma using T-cell transfer immunotherapy. Clin Cancer Res 2011; 17(13): 4550-4557, https://doi. org/10.1158/1078-0432.ccr-11-0116.

104. Rosenberg S.A., Restifo N.P. Adoptive cell transfer as personalized immunotherapy for human cancer. Science 2015; 348(6230): 62-68, https://doi.org/10.1126/science.aaa4967.

105. Zhang J., Zhu L., Zhang Q., He X., Yin Y., Gu Y., Guo R., Lu K., Liu L., Liu P., Shu Y. Effects of cytokineinduced killer cell treatment in colorectal cancer patients: a retrospective study. Biomed Pharmacother 2014; 68(6): 715720, https://doi.org/10.1016/j.biopha.2014.07.010.

106. Gao D., Li C., Xie X., Zhao P., Wei X., Sun W., Liu H.C., Alexandrou A.T., Jones J., Zhao R., Li J.J. Autologous tumor lysate-pulsed dendritic cell immunotherapy with cytokine-induced killer cells improves survival in gastric and colorectal cancer patients. PloS One 2014; 9(4): e93886, https://doi.org/10.1371/journal.pone.0093886.

107. Niu J., Ren Y., Zhang T., Yang X., Zhu W., Zhu H., Li J., Li J., Pang Y. Retrospective comparative study of the effects of dendritic cell vaccine and cytokine-induced killer cell immunotherapy with that of chemotherapy alone and in combination for colorectal cancer. Biomed Res Int 2014; 2014: 214727, https://doi.org/10.1155/2014/214727.

108. Zhu H., Yang X., Li J., Ren Y., Zhang T., Zhang C., Zhang J., Li J., Pang Y. Immune response, safety, and survival and quality of life outcomes for advanced colorectal cancer patients treated with dendritic cell vaccine and cytokineinduced killer cell therapy. Biomed Res Int 2014; 2014: 603871, https://doi.org/10.1155/2014/603871.

109. Parkhurst M.R., Yang J.C., Langan R.C., Dudley M.E., Nathan D.N., Feldman S.A., Davis J.L., Morgan R.A., Merino M.J., Sherry R.M., Hughes M.S., Kammula U.S., Phan G.Q., Lim R.M., Wank S.A., Restifo N.P., Robbins P.F., Laurencot C.M., Rosenberg S.A. T cells targeting carcinoembryonic antigen can mediate regression of metastatic colorectal cancer but induce severe transient colitis. Mol Ther 2011; 19(3): 620-626, https://doi.org/10.1038/ mt.2010.272.

110. Morgan R.A., Yang J.C., Kitano M., Dudley M.E., Laurencot C.M., Rosenberg S.A. Case report of a serious adverse event following the administration of T cells transduced with a chimeric antigen receptor recognizing ERBB2. Mol Ther 2010; 18(4): 843-851, https://doi.org/10.1038/mt.2010.24. 